\title{
The Nexus Between Business Profitability, Business Customer Relationships and Customer Loyalty: A Review of Existing Literature and Selected Studies
}

\author{
Paul Matshona \\ $\mathrm{PhD}$ candidate, Zimbabwe Open University
}

\begin{abstract}
This conceptual paper argues that the key to business profitability is management of customer relationships. The longer business keeps the customer satisfied the more profit the organisation makes. Studies have proven that failure to understand the public's perception of a business is detrimental to the success and profitability of a business. This may translate to a gradual death of the business. Thus, the relationship between a business and its customers should not only be maintained but continuously improved to create a strong bond between the firm and the customers. The paper argues that this strong bond sustains the company for ages whilst at the same time ensuring that customers always get value for their money.
\end{abstract}

Keywords: Customer, customer relationships, customer loyalty, customer profitability

DOI: $10.7176 / \mathrm{PPAR} / 9-3-10$

Publication date:March $31^{\text {st }} 2019$

\section{Introduction}

"A customer is king", goes the old adage. What this means is that in business practice, a customer is not only an ordinary stakeholder, but actually on top of the hierarchy. Just as a king is served with utmost respect and genuineness, a customer also ought to be treated the same. This takes us to the thrust of this paper, which is to measure and manage customer relationships. It has been discovered that failure to measure and know the public's perception of a business can lead to a gradual or even a sudden death of the business at some point. Equally important, the relationship between a business and its customers ought to be maintained and if possible improved at all costs to create a strong bond with the firm. It is this bond that sustains the company for ages whilst at the same time ensuring that customers always get value for their money. Such issues will be discussed in this paper.

\section{Dealing with customer relationships}

The key to success in business is determined by the company's ability to build strong customer relationships. According to Nikunen, Saarela, Oikarinen, Muhos, and Isohella (2017), good customer relationships help to attract customers; engage customers' interests and participation; retain customers; learn about customers' preferences; and relate to customers (p.173). Failure to manage customer relationships can lead to failure of the business venture because customers' perceptions about products and the company matter. Companies like CocaCola have mastered the art of learning and understanding their customers by always coming up with advertisements that capture the attention of customers. Even with their success, they still spend money on advertising.

Nikunen et al. (2017) posit that digital marketing can help engage customers interests and participation through engine optimization (p.174). Companies should take advantage of the availability of social media, such as Facebook, to keep in touch with customers. One great advantage of Facebook, according to Nikunen et al. (2017), "is customers' ability to communicate directly with companies about their needs" (p.176). Furthermore, companies are able "to learn about their customers, which contributes to learning customers' preferences, as well as relating to these customers" (p.176).

Dash, Kapoor, Mangesh Dash (2018) posit that in the competitive global business environment, "the customers' expectations are ever increasing" (p.4). Companies need to be responsive and sensitive to customers' expectations to remain competitive. According to Bhat, Darzi, and Parrey (2018), the customer has become a key element for any firms' long-term growth, sales and marketing strategy, resource allocation, product development, and overall profitability" (92-93). An important element to successful strategy success is customer knowledge management (CKM) and customer satisfaction (Bhat et al., 2018, p.92). More companies are investing in customer relationship management since they want to retain customers and to maximize profits (Alamgir \& Uddin, 2017, p.75). Järvinen \& Väätäjä (2018) posit that generally, "companies that understand which customers are profitable, and which ones are producing losses are equipped with valuable information that is necessary to increase their performance" (p.29).

Niraj, Gupta, \& Narasimhan (2001) posit that in this customer centric era, "firms should focus on building and managing customer equity and not just brand equity" (p.3). Alamgir \& Uddin (2017) carried a study to 
examine the role of customer relationship management (CRM) and relationship maintenance (RM) on customer retention (CR). The writers used a qualitative research methodology because the study technique was found to be more suitable. The researchers used semi-structured interview questions to gather data from participants. Each interview, according to Alamgir \& Uddin (2017), took more than an hour and was audio recorded with the participants' prior permission and were transcribed and thoroughly reviewed to find out the probable errors (p.81).

According to Bhat et al. (2018), customer loyalty is "a deeply held commitment to rebuy or re-patronize a preferred product/service consistently in the future, thereby causing repetitive same-brand or same-brand set purchasing, despite situational influences and marketing effort having the potential to cause switching behavior" (p.94). According to Elmontaser \& Jaafar Alhabshi (2016), focus of marketers has slowly shifted "from concentrating on improving operational performance to raised order constructs, such as customer loyalty and customer retention which are considered to contribute to company's long-term achievement" (p.185). Customers are concerned about service quality. Service quality, according to Elmontaser \& Jaafar Alhabshi (2016), is defined as "the customer's impression of the relative inferiority or superiority of the service provider and its services" (p.185). According to Elmontaser \& Jaafar Alhabshi (2016), the customer's impression is often considered "similar for the customer's overall attitude towards a company" (p.185). Loyalty, usually, is a result of customers' satisfaction of service provided by the company. According to Elmontaser \& Jaafar Alhabshi (2016), when a customer is satisfied with a company's services, "the customer's attitude towards the organization is improved and this kind of attitude will impact the customers' satisfaction of the company" (p.190). Elmontaser \& Jaafar Alhabshi (2016) posit that "satisfied customers are additionally likely to inform others of their favorable experiences and engage in positive word of mouth advertising" (p.193). On the other hand, dissatisfied customers are likely "to switch brands and engage with negative word-of-mouth advertising (Elmontaser \& Jaafar Alhabshi, 2016, p.193).

Elmontaser \& Jaafar Alhabshi (2016) posit that customer satisfaction is "the key of success in the present very competitive world of business" (p.193). Improved customer loyalty, according to Elmontaser \& Jaafar Alhabshi (2016), in service firms "has been proven to increase profitability" (p.193). Dash et al. (2018) posit that customer loyalty "is viewed as the strength of the relationship between an individual's relative attitude towards an entity (brand/service/store/vendor) and repeat patronage behavior" (p.3). Bhat et al. (2018) state that customer loyalty is crucial for both organization and customer (p.94).

Dash et al. (2018) carried out a study to assess the significance of customer loyalty and ways to build and strengthen customer loyalty for a brand, specifically in life insurance. The research used explorative study of literature on life insurance market, structure of life insurance distribution system, service standards and quality, relationship of service and quality, and customer satisfaction. The researchers found that outstanding service to customers can result in $75 \%$ of customer spending more, $80 \%$ of customers willing to pay more due to the great experience, and $50 \%$ of customers who had great experience are three times more likely to recommend the company to other potential customers (Dash et al, 2018, p.3). Dash et al. (2018) also concluded that "regardless of what "regardless of what the product or service is, customers feel happy when they experience recognition (positive strokes), courtesy, responsiveness, sensitivity, competence, reliability or credibility and ease of process" (p.4). The researchers concluded that "recognition is more vital than any other factors" (p.4). Future research should focus on what makes customers loyal to different brands other than insurance.

Elmontaser \& Jaafar Alhabshi (2016) posit that customer loyalty increases profitability and gives the firm competitive advantage (p.193). Instead of concentrating on financial measures, focusing on customers creates competitive advantage which can enable the company to gain market share resulting in company's profitability. A company can ensure its continued existence if it is able to understand its customers and their needs as well as meeting their expectations. Apple Inc is a good example of a company that has done a great job in meeting its customers' expectations. Its customers are loyal and choose to use only apple products despite their high prices. That loyalty has made Apple a very successful company yet some years back it struggled to gain market share in the electronics business. Epstein. Friedl, and Yathas (2008) posit that although almost all companies have processes for assessing the profitability of their products, "most are far behind in assessing their customers' profitability" (p.56). Managers who can understand the patterns of current customer relationships are able to make better decisions that results in an increase of cash flows from customers, and or reduce the volatility and vulnerability of cash flows" (Järvinen \& Väätäjä, 2018, p.29-30).

Managers need to ensure they get accurate information about customer profitability by using appropriate costing system. According to Niraj et al. (2001), an understanding of profitability at the individual customer level, "is important to distinguish the more profitable customers from the less profitable ones" (p.1). Niraj et al. (2001) posit that there is evidence that all customers dollars are not equal in their effect on the firm's net profits" (p.2). The differences in the cost of serving different customers play an equally important role in determining which customer is profitable and which is not. Niraj et al (2001) suggest that customer profitability has attracted attention in both management accounting and marketing literature (p.3). Lee, Lin, \& Chen (2010) posit that 
"relationship marketing assumes that firms can be more profitable if they identify the most profitable customers and invest disproportionate marketing resources in them" (p.3212). According to Lee et al. (2010), if a company manage to identify "customer segments beneficial to future profitability will create positive contributions and in turn improve operational performances going forward" (p.3212).

Järvinen \& Väätäjä (2018) carried a study on customer profitability. The customer profitability analysis was done using the interventionist research approach. The method, according to Järvinen \& Väätäjä (2018), "allows for the researchers' active participative cooperation with the actors in the field" (p.32). This model allows researchers to get the insider understanding of what is happening in the case organization (Järvinen \& Väätäjä, 2018, p.32). The researchers investigated "how companies with different customer relationships make use of time-driven activity-based costing (TBABC) in their customer profitability analysis” (Järvinen \& Väätäjä, 2018, p.32). Järvinen \& Väätäjä (2018) investigated three companies that had a variety of customer interfaces that had implemented TBABC systems (p.32). The TBABC model, according to Järvinen \& Väätäjä (2018), "was able to pinpoint what caused the cost of the same product to vary significantly by customer, and what handling procedure decision was used" (p.35). The researchers found that, in support of Krumwiede \& Charles (2014), firms benefit from ABC methodology in relation to customer-focused strategies (p.43). The authors also found that firms need to build their capacity to improve profitability. Future research should focus on how costing systems can help managers when making decisions about customer profitability.

\section{Conclusion}

This paper argued that customer is king. Organisations should ensure that they maintain long-term relationships with their customers to ensure optimum profitability of their businesses. Studies carried out like those by Dash et al. (2018) and Järvinen \& Väätäjä (2018) have proven that profitability of business depends on the company's relationships with its customers. It is therefore recommended that all organisations (whether public or private) should ensure that they build long term relationships with their customers.

\section{References}

Alamgir, M., \& Uddin, M. N. (2017). The Role of Customer Relationship Management and Relationship Maintenance on Customer Retention- an Exploratory Study. Journal of Services Research, 17(2), 72-86. Retrieved from http://proxy1.ncu.edu/login?url=https://search.ebscohost.com/login.aspx?direct=true \&db=bth\&AN=1274397 19\&site=eds-live

Bhat, S. A., Darzi, M. A., \& Parrey, S. H. (2018). Antecedents of Customer Loyalty in Banking Sector: A Mediational Study. Vikalpa: The Journal for Decision Makers, 43(2), 92-105. https://doiorg.proxy1.ncu.edu/10.1177/0256090918774697

Dash, S. K., Kapoor, P., \& Mangesh Dash, R. K. S. (2018). A Study Towards Customer Loyalty in Life Insurance. CLEAR International Journal of Research in Commerce \&\&\#160; Management, 9(7), 1-5. Retrieved from http://proxy1.ncu.edu/login?url=https://search.ebscohost.com/login.aspx?direct=true\&db=bth\&AN=1316236 73\&site $=$ eds-live

Elmontaser, M. A., \& Jaafar Alhabshi, S. M. B. S. (2016). The Impact of Service Quality on Malaysian Muslim Islamic Bank Customers: Satisfaction, Loyalty and Retention. Al-Shajarah: Journal of the International Institute of Islamic Thought \& Civilization, 21, 183-215. Retrieved from http://proxy1.ncu.edu/login?url=https://search.ebscohost.com/login.aspx?direct=true\&db=tsh\&AN=1206375 $98 \&$ site $=$ eds-live

Epstein, M. J., Friedl, M., \& Yuthas, K. (2008). Managing Customer Profitability. Journal of Accountancy, 206(6), 54-59. $\quad$ Retrieved from http://proxy1.ncu.edu/login?url=https://search.ebscohost.com/login.aspx?direct=true\&db=bth\&AN=3554945 $0 \&$ site $=$ eds-live

Järvinen, J., \& Väätäjä, K. (2018). Customer Profitability Analysis Using Time-Driven Activity-Based Costing: Three Interventionist Case Studies. Nordic Journal of Business, 67(1), 27-47. Retrieved from http://proxy1.ncu.edu/login?url=https://search.ebscohost.com/login.aspx?direct=true\&db=bth\&AN=1314427 $28 \&$ site $=$ eds-live

Lee, C, Lin, T. T., \& Chen, C. (2010). The determinant of customer profitability on the financial institution. Service Industries Journal, 30(14), 2311-2328. https://doi-org.proxy1.ncu.edu/10.1080/02642060802629901

Nikunen, T, Saarela, M, Oikarinen, E, Muhos, M, \&, Isohella, L (2017). In: Management, Vol 12, Is 2, Pp 171188 (2017); University of Primorska, 2017. Language: English, Database: Directory of Open Access Journals

Niraj, R. (2001). Customer Profitability in a Supply Chain. Journal of Marketing, 65(3), 1-16. Retrieved from http://proxy1.ncu.edu/login?url=https://search.ebscohost.com/login.aspx?direct=true\&db=bth\&AN=4856369 \&site=eds-live 